\title{
Peranan Lembaga Amil Zakat Infak dan Sedekah Muhammadiyah dalam Kesejahteraan Masyarakat: Bukti dari Kalimantan Tengah
}

\author{
Muhammad Riza Hafizi', Putri Mei Ismil Kholifah² \\ ${ }^{1,2}$ Institut Agama Islam Negeri Palangka Raya \\ 1,2 Jl. G. Obos Kompleks Islamic Centre Kota Palangka Raya, Kalimantan Tengah \\ Email: riza.hafizi@iain-palangkaraya.ac.id
}

\begin{abstract}
Abstrak
Penelitian ini bertujuan untuk mengetahui peranan lembaga amil zakat infaq dan sedekah Muhammadiyah dalam kesejahteraan masyarakat. Pendekatan penelitian ini menggunakan metodologi kualitatif, dengan menggunakan metode kualitatif deskriptif melalui wawancara semi terstruktur, teknik observasi dan dokumentasi. Sedangkan teknik pengabsahan data menggunakan teknik triangulasi sumber. Analisis data menggunakan metode collections, reduction, display and verification. Berdasarkan hasil penelitian yang telah dilakukan diketahui bahwa peranan LAZISMU dalam kesejahteraan masyarakat dimana mekanisme pengumpulan dana menggunakan beberapa metode yaitu pengumpulan digital fundraising, datang langsung, jemput langsung dan via transfer. Kedua, pendistribusian dana ZIS dilakukan oleh pengurus LAZISMU dibantu para relawan didukung dengan adanya database masyarakat yang berhak menerima bantuan sehingga mempermudah dalam road map pendistribusian. Ketiga, hasil penelitian menemukan bahwa perubahan sosial ekonomi masyarakat penerima bantuan dana ZIS sangat terbantu dengan adanya bantuan yang didapatkan, serta dengan adanya pandemi Covid 19, pengurus LAZISMU mengadakan program siaga Covid 19.
\end{abstract}

Kata kunci: Lembaga Amil Zakat, LAZISMU, Kesejahteraan, ZIS, Distribusi

\begin{abstract}
This study aims to determine the role of the amil zakat infaq and alms Muhammadiyah institutions in the welfare of society. This research approach uses a qualitative methodology, using qualitative descriptive methods. Qualitative data through semi-structured interviews observation and documentation are also used. Meanwhile, the data validation technique used the source triangulation technique. Data analysis uses the collections, reduction, display, and verification methods. Based on the results of the research that has been done, it is known that LAZISMU's role in the welfare of the community where the fundraising mechanism uses several methods, namely digital fundraising collection, coming directly, direct pick-up, and via transfer. Second, the distribution of ZIS funds is carried out by LAZISMU management assisted by volunteers supported by a database of people who are entitled to receive assistance to simplify the distribution road map. Third, the results of the study found that the socio-economic changes of the community receiving ZIS funds were greatly helped by the assistance that was received, and with the Covid 19 pandemic, LAZISMU management held a Covid 19 alert program.
\end{abstract}

Keywords: Amil Zakat Institution, LAZISMU, Welfare, ZIS, Distribution 


\section{4 |Peranan Lembaga Amil Zakat Infak dan Sedekah Muhammadiyah dalam Kesejahteraan Masyarakat: Bukti dari Kalimantan Tengah}

\section{PENDAHULUAN}

Zakat, Infak, sedekah (ZIS) merupakan amaliah ibadah dalam Islam yang memiliki keselarasan dengan upaya untuk mengatasi kekurang mampuan. Islam yang bertujuan untuk mewujudkan keadilan sosial melalui mekanisme distribusi kekayaan dari yang kaya kepada orang kurang mampu, secara normatif, Islam memandang bahwa di dalam harta orang-orang kaya terdapat hak orang-orang kurang mampu. Membayarkan zakat berarti menyucikan harta sebagaimana makna lughawy zakat yang memiliki arti suci atau menyucikan (Kholiq, 2012). Memperbincangkan Zakat dalam perspektif lainnya, maka menjalankan kewajiban pembayaran zakat, juga diyakini dapat digunakan sebagai alternatif untuk mengetaskan kekurang mampuan di tengah-tengah masyarakat (Hafidhuddin, 2008). Dalam Islam, pemberantasan kekurang mampuan dilembagakan dalam salah satu rukunnya, yaitu zakat oleh karena itu diperlukan pengelolaan zakat yang amanah, transparan, dan profesional. Pada saat ini penyaluran zakat fitrah, zakat maal ataupun infak dan sedekah telah terkoordinasi dengan baik. Dana ZIS yang diterima dikelola untuk pengembangan ekonomi guna meningkatkan kualitas hidup bagi penerima dana ZIS.

Kekurangmampuan merupakan bahaya besar bagi umat manusia dan tidak sedikit umat yang jatuh peradabannya hanya karena kefakiran. Salah satu cara menanggulangi kekurang mampuan adalah dukungan orang yang mampu untuk mengeluarkan harta kekayaan mereka berupa dana Zakat, Infak, sedekah (ZIS) kepada mereka yang kekurangan (Sartika, 2008). Islam menjadikan instrument zakat untuk memastikan keseimbangan pendapatan di masyarakat. Pengeluaran dari zakat adalah pengeluaran minimal untuk membuat distribusi pendapatan menjadi lebih merata (Andriyant, 2014). Salah satu yang menunjang kesejahteraan hidup di dunia dan di akhirat adalah adanya kesejahteraan sosial-ekonomi. Orang kurang mampu juga merasa dihargai karena ada empati dari orang yang mampu. ZIS bisa berfungsi sebagai modal kerja bagi orang kurang mampu untuk dapat membuka lapangan pekerjaan, sehingga bisa berpenghasilan dan dapat memenuhi kebutuhan sehari-harinya (Atabik, 2015).

Adapun target maksimal dari realisasi Zakat adalah dengan meningkatkan standar kehidupan golongan fakir kurang mampu hingga dapat mencapai tingkat kehidupan yang berkecukupan (Qaradhawi, 2005). Masyarakat kurang mampu yang ada di Kabupaten Pulang Pisau, Kalimantan Tengah sedikit terbantu dengan adanya ZIS dari orang-orang yang mempunyai kelebihan harta. Masyarakat yang ada di Kecamatan Kahayan Hilir sendiri memiliki jumlah penduduk yaitu Penduduk Kecamatan Kahayan Hilir berdasarkan proyeksi penduduk tahun 2018 sebanyak 27.812 jiwa, yang terdiri atas 14.405 jiwa penduduk laki-laki dan 13.407 jiwa penduduk perempuan, pada tahun 2019 ada peningkatan jumlah penduduk yang cukup besar yaitu 30.130 Jiwa. Luas wilayah sebesar $360 \mathrm{~km} 2$, dengan desa yang terluas adalah Desa Buntoi yakni sebesar 25 \% dari luas wilayah kecamatan (BPS, 2019).

JISFIM: Journal of Islamic Social Finance Management, Volume 2, No 1 Tahun 2021 http://jurnal.iain-padangsidimpuan.ac.id/index.php/JISFIM 
LAZISMU Pulang Pisau juga ikut membantu menanggulangi pencegahan penyebaran wabah virus yang saat ini terjadi diseluruh dunia yaitu Virus Corona (Covid 19), dengan penyemprotan disinfektan dan pembersihan di masjid, musholla, sekolah dan fasilitas publik lainnya dan program ketahanan pangan di daerah Kalimantan Tengah khususnya di Kecamatan Kahayan Hilir Kabupaten Pulang Pisau. Disamping itu juga banyak programprogram yang di jalankan selama adanya wabah virus corona ini (Covid 19) yang dilaksanakan oleh LAZISMU Pulang Pisau (BPS, 2019). Berdasarkan permasalahan yang terindentifikasi diatas, sangat penting untuk diteliti, maka dari itu. Penelitian ini bertujuan untuk meneliti peranan lembaga amil zakat infak dan sedekah Muhammadiyah (LAZISMU) dalam kesejahteraan masyarakat di Kabupaten Pulang Pisau, Kalimantan Tengah

\section{KAJIAN TEORITIS}

Peran diartikan sebagai perangkat tingkah yang diharapkan dimiliki oleh orang yang berkedudukan dalam masyarakat. Sedangkan peranan merupakan tindakan yang dilakukan oleh seorang dalam suatu peristiwa (Mukmin, 2014). Peranan (role) merupakan aspek dinamis kedudukan (status). Apabila seseorang melaksanakan hak dan kewajibannya sesuai dengan kedudukannya, dia menjalankan suatu peranan. Pembedaan antara kedudukan dengan peranan adalah untuk kepentingan ilmu pengetahuan. Keduanya tak dapat dipisah-pisahkan karena yang satu tergantung pada yang lain dan sebaliknya. Tak ada peranan tanpa kedudukan atau kedudukan tanpa peranan. Setiap orang mempunyai macam-macam peranan yang berasal dari pola-pola pergaulan hidupnya (Mukmin, 2014).

Peranan merupakan kata peran yang mendapatkan imbuhan dengan akhiran -an. Maknanya jika dilihat dalam KBBI (Kamus Besar Bahasa Indonesia) adalah tindakan yang dilakukan oleh seseorang dalam suatu peristiwa. Jika kata peranan dimasukkan dalam sebuah kalimat yang memiliki subyek, maka bisa bermakna tindakan yang dilakukan oleh subyek tertentu dalam suatu peristiwa. Oleh karena itu, ketika kata peranan disandingkan dengan kata zakat seperti pada kalimat peranan zakat, maka dapat diartikan sebagai tindakan yang dilakukan oleh zakat dalam suatu peristiwa (KBBI, n.d.)

\section{Zakat, Infak dan Sedekah}

Zakat termasuk rukun Islam, Zakat mulai disyari'atkan pada bulan syawal tahun kedua Hijriyah sesudah pada bulan Ramadhan diwajibkan zakat fitrah, kemudian diwajibkan zakat maal atau kekayaan Zakat dari segi bahasa berarti "Berkah, Bersih, Baik dan Meningkat". Sedangkan secara bahasa At-Thaharah (kesucian), Al-barakah (keberkahan), An-Nama' (pertumbuhan/perkembangan) (Teuku Muhammad Hasbi Ash Shiddiqy, 2006). Penjelasan makna secara harfiah tersebut mengerucut pada pengertian zakat sebagai proses pembersihan 


\section{6 |Peranan Lembaga Amil Zakat Infak dan Sedekah Muhammadiyah dalam Kesejahteraan Masyarakat: Bukti dari Kalimantan Tengah}

diri yang didapatkan setelah pelaksanaan kewajiban membayar zakat. Sedangkan pengertian zakat menurut syara' yaitu memberikan sebagian harta kepada yang berhak menerimanya sesuai dengan aturan-aturan yang telah ditentukan dalam Al-Qur'an (Fazlur Rahman, 1996).

Madzhab Maliki mendefinisikan zakat dengan mengeluarkan sebagian harta yang khusus yang telah mencapai nishab kepada orang-orang yang berhak menerimanya. Sedangkan menurut madzhab Hambali zakat ialah hak yang wajib dikeluarkan dari harta yang khusus untuk kelompok yang khusus pula (Fanani, 2000). Di dalam Al-Qur'an, Allah SWT telah menyebutkan tentang zakat dan shalat sejumlah 82 ayat. Dari sini dapat disimpulkan bahwa setelah shalat, zakat merupakan rukun Islam terpenting. Pelaksanaan shalat melambangkan baiknya hubungan seseorang dengan Tuhannya, sedangkan zakat adalah lambang harmonisnya hubungan antar sesama manusia. Hal ini menunjukkan bahwa zakat mempunyai arti yang sangat signifikan baik dalam kehidupan religi dan sosial (Fanani, 2000). Adapun beberapa tujuan zakat adalah sebagai berikut pertama, mengangkat derajat fakir miskin dan membantunya keluar dari kesulitan hidup dan penderitaan. Kedua, membantu memecahkan masalah yang dihadapi oleh orang yang berutang, ibnu sabil, dan mustahiq lainnya. Ketiga, membina tali persaudaraan sesama umat Islam. Keempat, menghilangkan sifat kikir dari pemilik harta. Kelima, membersihkan sifat dengki dan iri hati dari orang-orang kurang mampu. Keenam, menjembatani jurang pemisah antara yang kaya dengan yang kurang mampu dalam suatu masyarakat. Ketujuh, mengembangkan rasa tanggung jawab sosial pada diri seseorang, terutama pada mereka yang mempunyai harta dan terakhir mendidik manusia untuk berdisplin menunaikan kewajiban dan menyerahkan hak orang lain yang ada padanya.

Orang-orang yang berhak menerima zakat, pertama fakir, adalah orang yang tidak mempunyai harta dan usaha, atau mempunyai harta atau usaha yang kurang dari seperdua kecukupannya, dan tidak ada orang yang berkewajiban memberi belanjanya. Kedua, kurang mampu, adalah orang yang mempunyai harta atau usaha sebanyak seperdua kecukupannya atau lebih, tetapi tidak sampai mencukupi (Sulaiman Rasjid, 1992). ketiga, amil zakat, adalah pengurus zakat yang ditunjuk oleh pemimpin atau wakilnya. Mereka bertugas mengumpulkan zakat dari orang-orang kaya, menjaga, menghitung dan membaginya. Keempat, muallaf, adalah orang yang diberi zakat dengan maksud melunakkan hati mereka atau untuk meneguhkan hati mereka di atas Islam. Kelima, budak, maksud al-Riqob disini adalah para budak yang mukatab, yang dijanjikan akan merdeka bila membayar sejumlah harta kepada tuannya. Budak yang telah mengikat perjanjian yang sah dengan tuannya, tetapi tidak mampu membayarnya dapat diberikan zakat untuk membantu mereka memerdekakan dirinya. Keenam, gharim, adalah orang yang menanggung utang dan tidak mampu melunasi. Ketujuh, fisabilillah, Yang termasuk ke dalam kelompok Fi sabilillah ini adalah mereka para pejuang yang berperang di jalan Allah secara suka rela tanpa mendapatkan bayaran. Sehingga mereka

JISFIM: Journal of Islamic Social Finance Management, Volume 2, No 1 Tahun 2021 http://jurnal.iain-padangsidimpuan.ac.id/index.php/JISFIM 
berhak untuk menerima zakat, tetapi meskipun mereka termasuk orang yang berjuang atau berperang di jalan Allah dan mendapatkan gaji maka mereka tidak boleh untuk menerima zakat. Terakhir, ibnu sabil, adalah musafir yang berada jauh dari negerinya, kehabisan uang atau terjadi sesuatu yang menghabiskan seluruh uangnya (Ali Mahmud Uqaily, 2017).

Infak ditinjau dari segi bahasa berarti "membelanjakan”, Sedangkan menurut syari'at Infaq adalah mengeluarkan sebagian dari harta atau pendapatan (penghasilan) untuk suatu kepentingan kemanusiaan yang diperintahkan ajaran Islam (Abdul Mujieb \& Mabruri Tholhah Syafi'ah, 1994). Dalam kajian fiqh Islam infak dibedakan dari zakat dan shadaqah, zakat merupakan derma yang sudah ditetapkan jenis, jumlah dan waktu pelaksanaannya sedangkan infak tidak ada ketentuan mengenai jenis dan jumlah harta yang akan dikeluarkan serta tidak ditentukan kepada siapa diberikan (Abdul Mujieb \& Mabruri Tholhah Syafi'ah, 1994). Sedangkan sedekah berasal dari kata shodaqa yang terdiri dari tiga huruf Shod-dal-qaf, berarti sesuatu yang benar atau jujur.sedekah bisa diartikan mengeluarkan harta di jalan Allah, sebagai bukti kejujuran atau kebenaran iman seseorang. Sedekah adalah pemberian berupa sesuatu yang berguna bagi orang lain yang memerlukan bantuan (fakir, miskin) dengan tujuan beribadah (mencari pahala) kepada Allah semata. Sedekah pada prinsipnya sama dengan infaq hanya saja sedekah memiliki pengertian yang lebih luas. Sedekah dapat berupa bacaan tahmid, takbir, tahlil, istighfar maupun bacaan-bacaan kalimat tayyibah lainnya, sedekah juga dapat berupa pemberian benda atau uang, bantuan tenaga atau jasa serta menahan diri dari tidak berbuat kejahatan. Sedekah adalah keseluruhan amal kebajikan yang dilakukan setiap pribadi muslim untuk menciptakan kesejahteraaan sesama umat manusia, termasuk untuk kelestarian lingkungan hidup dan alam semesta ciptaan illahi guna memperoleh hidayah dan ridha Allah Subhanahu Wa Ta'ala (Makhlul Ilmi, 2002).

\section{Tabel 1.}

\section{Persamaan dan Perbedaan Zakat, Infak dan Sedekah}

\begin{tabular}{llllll}
\hline \multicolumn{2}{l}{ Zakat } & \multicolumn{2}{l}{ Infak } & \multicolumn{2}{l}{ Sedekah } \\
\hline Definisi & Hak yang wajib dalam & Menafkahkan & sesuatu & Menafkahkan sesuatu kepada \\
& waktu tertentu untuk & kepada orang lain dengan & orang lain dengan ikhlas dan \\
& golongan tertentu. & ikhlas dan karena Allah & karena Allah semata \\
& & & semata & \\
\hline Hukum & Wajib apabila telah & Wajib dan sunnah & Sunnah \\
& mencapai nisab & & & & \\
\hline Waktu & Ada batasan & dan & Terus menerus tanpa ada & Terus menerus tanpa ada \\
& musiman (haul) & & batasan & batasan & Berupa materi dan non materi
\end{tabular}

Sumber: diolah peneliti

JISFIM: Journal of Islamic Social Finance Management, Volume 2, No 1 Tahun 2021 http://jurnal.iain-padangsidimpuan.ac.id/index.php/JISFIM 


\section{Kesejahteraan Masyarakat}

Kesejahteraan merupakan titik ukur bagi masyarakat yang berarti bahwa telah berada pada kondisi yang sejahtera. Pengertian kesejahteraan menurut kamus bahasa Indonesia berasal dari kata sejahtera yang mempunyai makna aman, sentosa, makmur, dan selamat, terlepas dari segala macam gangguan, kesukaran, dan sebagainya. Kata sejahtera mengandung pengertian dari bahasa sansekerta "catera" yang berarti payung. Dalam konteks kesejahteraan, "catera" adalah orang yang sejahtera, yakni orang yang dalam hidupnya bebas dari kekurang mampuan, kebodohan, ketakutan, atau kekhawatiran sehingga hidupnya aman dan tentram, baik secara lahir maupun batin (Departemen Pendidikan Nasional, 2005). Undang-Undang Nomor 13 tahun 1998 menjelaskan juga tentang arti dari kesejahteraan. Kesejahteraan didefinisikan sebagai suatu tata kehidupan dan penghidupan sosial baik material maupun spiritual yang diliputi rasa keselamatan, kesusilaan, dan ketentraman lahir batin yang memungkinkan bagi setiap warga negara untuk mengadakan pemenuhan jasmani, rohani, dan sosial yang sebaik-baiknya bagi diri, keluarga, serta masyarakat dengan menjunjung tinggi hak dan kewajiban asasi manusia sesuai dengan Pancasila (Almizan, 2016).

Konsep "kesejahteraan" yang memasukkan tujuan kemanusiaan dan keruhaniaan, tentu akan berakibat pada keharusan mendiskusikan secara ilmu ekonomi apa hakekat tujuan kesejahteraan tersebut dan bagaimana merealisasikannya. Tujuan-tujuan konsep kesejahteraan tersebut tidak hanya mencakup soal kesejahteraan ekonomi dalam arti materi semata, tetapi juga mencakup permasalahan persaudaraan manusia dan keadilan sosialekonomi, kesucian kehidupan, kehormatan individu, kehormatan harta, kedamaian jiwa dan kebahagiaan, serta keharmonisan kehidupan keluarga dan masyarakat.

\section{METODE PENELITIAN}

Pendekatan yang dilakukan pada penelitian ini menggunakan metodologi kualitatif, dengan menggunakan metode kualitatif deskriptif. Data kualitatif melalui wawancara semi terstruktur dikumpulkan dari 2 subjek utama yaitu ketua dan sekretaris LAZISMU, 7 partisipan yang terdiri dari masyarakat penerima dana ZIS yaitu masyarakat kurang mampu, janda, kaum dhuafa dan guru. Wawancara berlangsung antara 45 dan 60 menit. Selain itu, menggunakan teknik observasi dan dokumentasi digunakan untuk memberikan lebih jauh peranan LAZISMU dalam kesejahteraan masyarakat kurang mampu untuk menguatkan bentuk bukti lain. Sedangkan teknik pengabsahan data menggunakan teknik triangulasi sumber. Analisis data collections, reduction, display and verification. 


\section{Gambaran Umum Kabupaten Pulang Pisau}

Kecamatan yang memiliki luas wilayah terbesar adalah Kecamatan Sebangau Kuala yaitu seluas $380.100 \mathrm{~km} 2$ atau 42,25\% dari total luas wilayah Kabupaten Pulang Pisau. Sedangkan kecamatan yang memiliki luas wilayah paling sempit adalah Kecamatan Kahayan Hilir dengan persentase luas $4 \%$ dari luas wilayah Kabupaten Pulang Pisau yang ditunjukkan oleh tabel (BPS, 2019).

Tabel 2.

Luas Wilayah Kabupaten Pulang Pisau

\begin{tabular}{|c|c|c|c|c|c|c|}
\hline \multirow[t]{4}{*}{ No. } & \multirow[t]{4}{*}{ Kecamatan } & \multirow{4}{*}{$\begin{array}{l}\text { Jumlah } \\
\text { Kelurahan/ } \\
\text { Desa }\end{array}$} & \multicolumn{4}{|c|}{ Luas Wilayah } \\
\hline & & & \multicolumn{2}{|c|}{ Administrasi } & \multicolumn{2}{|c|}{ Terbangun } \\
\hline & & & (ha) & $(\%)$ & (ha) & (\%) thd total \\
\hline & & & & total & & \\
\hline 1. & Kahayan Kuala & 13 & $115 \cdot 500$ & 12,84 & 1.155 & 12,84 \\
\hline 2. & Sebangau Kuala & 8 & 380.100 & 42,25 & 3.801 & 42,25 \\
\hline 3. & Padih Batu & 16 & 53.586 & 5,96 & 536 & 5,96 \\
\hline 4. & Maliku & 15 & 41.314 & 4,59 & 413 & 4,59 \\
\hline 5. & Kahayan Hilir & 10 & 36.000 & 4,00 & 360 & 4,00 \\
\hline 6. & Jabiren Raya & 8 & 132.300 & 14,70 & 1.323 & 14,70 \\
\hline 7. & Kahayan Tengah & 14 & 78.300 & 8,70 & 783 & 8,70 \\
\hline \multirow[t]{2}{*}{8.} & Banama Tingang & 15 & 62.600 & 6,96 & 626 & 6,96 \\
\hline & Jumlah & 99 & 899.700 & 100,00 & 8.997 & 100,00 \\
\hline
\end{tabular}

Sumber: BPS Kabupaten Pulang Pisau, Tahun 2013-2018

LAZISMU adalah lembaga zakat tingkat nasional yang berkhidmat dalam pemberdayaan masyarakat melalui pemberdayaan masyarakat melalui pendayagunaan secara produktif dana zakat, infak, wakaf dan dana kedermawanan lainnya baik dari perseorangan, lembaga, perusahaan dan intansi lainnya. Didirikan oleh Pimpinan Pusat Muhammadiyah pada tahun 2002, selanjutnya dikukuhkan oleh Menteri Agama Republik Indonesia sebagai Lembaga Amil Zakat Nasional melalui SK No. 457/21 November 2002. Dengan telah berlakunya UndangUndang Zakat nomor 14 tahun 2014, dan keputusan Menteri Agama Republik Indonesia nomor 333 tahun 2015. LAZISMU sebagai Lembaga Ami Zakat Nasional telah dikukuhkan kembali melalui SK Mentri Agama Republik Indonesia nomor 730 tahun 2016.

Lembaga Amil Zakat Infak dan Sedekah Muhammadiyah (LAZISMU) Pulang Pisau sebagai lembaga amil zakat nasional telah dikukuhkan kembali melalui SK Mentri Agama Republik Indonesia nomor 730 tahun 2016. LAZISMU Pulang Pisau diangkat dan ditetapan oleh pengurus LAZISMU pimpinan wilayah Muhammadiyah Kalimantan Tengah Nomor JISFIM: Journal of Islamic Social Finance Management, Volume 2, No 1 Tahun 2021 http://jurnal.iain-padangsidimpuan.ac.id/index.php/JISFIM 
:o08.Kep/BP/18/B/2018, pada tanggal 29 Sya'ban 1439 H, bertepatan dengan tanggal 15 Mei 2018, di Palangka Raya, dengan susunan pengurus Dewan Syariah, Dewan Pengawas, dan Badan Pengurus Yaitu Ketua, Wakil Ketua, Sekretaris dan Anggota. LAZISMU di Pulang Pisau itu sendiri berdiri kurang lebih sudah 1 tahun dengan mempunyai banyak program penyaluran dana ZIS yaitu Santunan Dhu'afa, Tanggap Darurat dan Recovery Bencana, Backto Masjid/ Mushola, Dana Bergulir (Zakat Produktif), BUEKA (Bina Usaha Ekonomi Kelurga), Bea Siswa Pendidikan dan Peduli Guru.

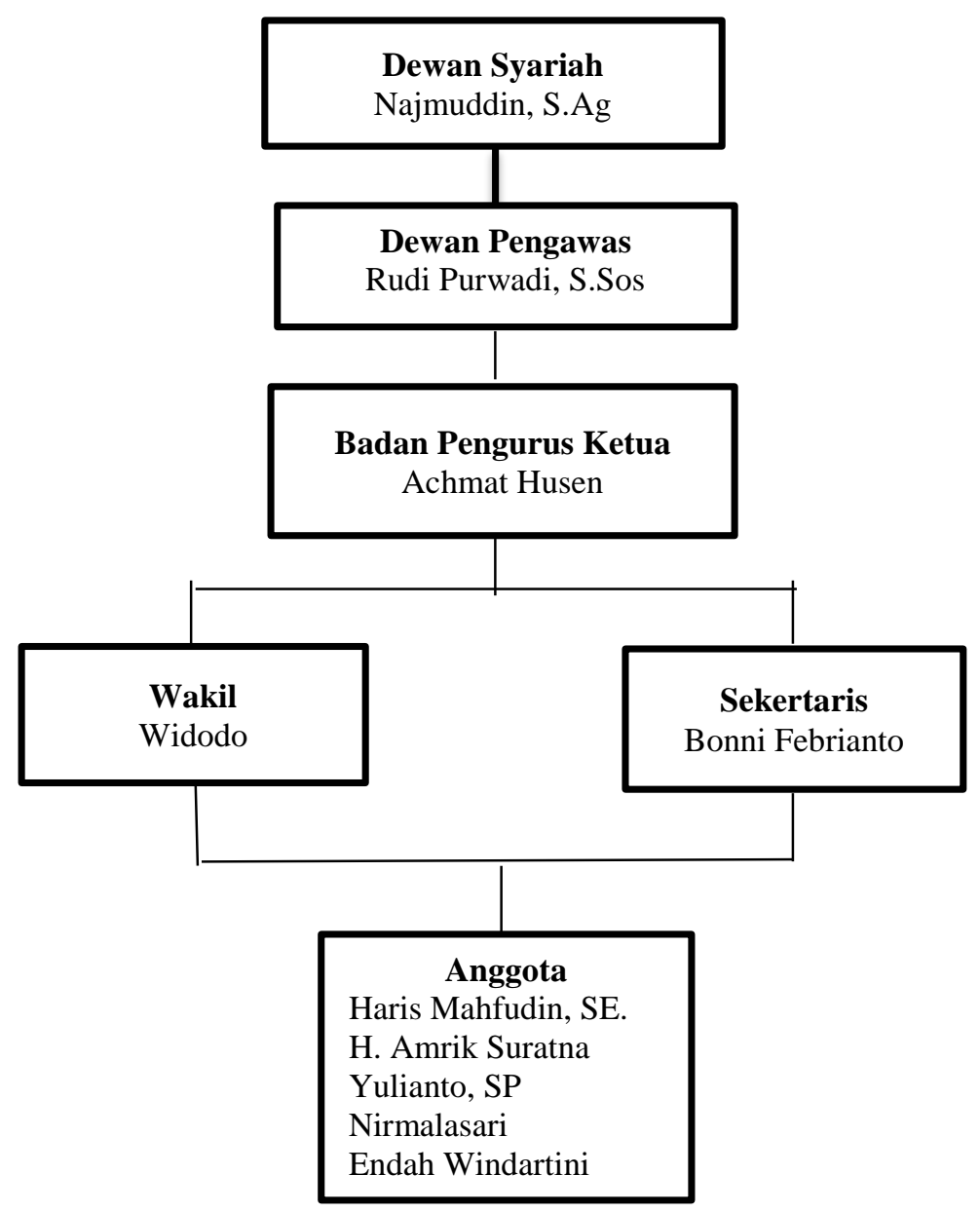

\section{Gambar 1. Struktur Organisasi LAZISMU Pulang Pisau}

\section{HASIL DAN PEMBAHASAN}

Berdasarkan hasil observasi, wawancara, dan dokumentasi terdapat tiga mekanisme pengumpulan dana zakat, infak dan sedekah yang dilakukan oleh LAZISMU Pulang Pisau, yang pertama dilakukan dengan cara mengumpulkan data yang didapat dari pihak ketiga yakni pertama Bank yaitu Bank BNI yang sudah bekerja sama dengan LAZISMU Pulang Pisau yang kedua dengan cara langsung tanpa perantara pihak ketiga yakni muzzaki mendatangi langsung ke kantor sekretariat LAZISMU Pulang Pisau dan yang ketiga para pengurus atau amil JISFIM: Journal of Islamic Social Finance Management, Volume 2, No 1 Tahun 2021 http://jurnal.iain-padangsidimpuan.ac.id/index.php/JISFIM 
menjumput langsung dana zakat, infak dan sedekah pada muzzaki. Setelah pengumpulan Zakat selesai pihak LAZISMU Pulang Pisau mempubilkasikan melalui media sosial, agar masyarakat lebih mudah mengetahui. Hal ini disampaikan oleh ketua dan sekertaris LAZISMU Pulang Pisau. Berdasarkan apa yang telah dikatakan ketua dan sekertaris LAZISMU Pulang Pisau tentang mekanisme pengumpulan dana ZIS yaitu dengan tiga cara yaitu via transfer melalui rekening bank, datang langsung ke kantor LAZISMU Pulang Pisau dan jemput langsung. Dalam mekanisme pengumpulan dana ZIS yang melalui via transfer ini, ada juga pengumpulan digital Fundraising ini sama saja dengan via transfer, Cuma bedanya disini digital Fundraising melalui aplikasi seperti Ovo, Link Aja dll.Digital Fundraising yaitu salah satu upaya penghimpunan donasi melalui internet/web, yang berdonasi bisa dari mana saja. Dana yang terkumpul masuk ke rekening LAZISMU Pusat, tetapi LAZISMU daerah bisa mengambil dananya dengan mengajukan surat ke pusat untuk diproses.

Disamping itu juga pengurus juga mempuanyai program kaleng infak yang bisanya mereka sebar kejalan-jalan dengan dibantu beberapa relawan LAZISMU Pulang Pisau dan kaleng infak ini juga disebar kepada para donatur yaitu ditempat mereka kerja dan dijemput tiap periodik. Dimana jumlah dana ZIS yang terkumpul pada tahun 2019 sebesar Rp. 85.849.781 dana ZIS ini digunakan untuk pendistribusian kepada masyarakat kurang mampu dan untuk biaya adminitrasi. Sedangkan untuk tahun 2020 dana ZIS yang terkumpul pada awal tahun kurang lebih sebesar Rp. 93.000.00o dana ZIS ini dikumpulkan dari donaturdonatur yang ada di Pulang Pisau maupun luar wilayah. Dana ZIS yang terkumpul pada tahun 2020 ini digunakan untuk penanggangan siaga darurat Covid 19 dan untuk bantuan setiap bulan kepada masyarakat kurang mampu yang telah di data oleh pengurus LAZISMU Pulang Pisau. Dimana jumlah dana ZIS yang terkumpul pada tahun 2019 sebesar Rp. 85.849.781 dana ZIS ini digunakan untuk pendistribusian kepada masyarakat kurang mampu dan untuk biaya adminitrasi. Sedangkan untuk tahun 2020 dana ZIS yang terkumpul pada awal tahun kurang lebih sebesar Rp. 93.000.00o dana ZIS ini dikumpulkan dari donatur-donatur yang ada di Pulang Pisau maupun luar wilayah. Dana ZIS yang terkumpul pada tahun 2020 ini digunakan untuk penanggangan siaga darurat Covid 19 dan untuk bantuan setiap bulan kepada masyarakat kurang mampu yang telah di data oleh pengurus LAZISMU Pulang Pisau.

Tabel 3.

Data Pengumpulan ZIS

\begin{tabular}{lccccc}
\hline Penghimpunaan & \multicolumn{3}{c}{} & & \multicolumn{2}{c}{ Jumlah Muzaki } \\
\hline Zakat & Infak dan Sedekah & DSKL & Jumlah & Muzaki & Muzaki \\
& & & & Individu & Badan \\
\hline Rp. 61.321.004 & Rp. 24.528.777 & - & Rp. 85.849.781 & 136 & 1
\end{tabular}

Sumber: diolah peneliti

JISFIM: Journal of Islamic Social Finance Management, Volume 2, No 1 Tahun 2021 http://jurnal.iain-padangsidimpuan.ac.id/index.php/JISFIM 
Dari hasil wawancara dengan Ketua dan Sekertaris LAZISMU Pulang Pisau bahwa pendistribusian dana zakat, infak dan sedekah yang dilakukan oleh pengurus LAZISMU Pulang Pisau, ini merupakan pendistribusian dana ZIS yang diberikan setiap bulannya kepada masyarakat kurang mampu yang mana sudah ada data base penerima bantuan dana ZIS. Dan untuk pendistribusian dana ZIS dalam penanggulangan Covid 19 dibantu dengan para relawan khusus yaiu MDMC, pemuda dan relawan Muhammadiyah.

Tabel 4 .

Data Penerima Bantuan Zakat Infak dan Sedekah Tahun 2019-2020

\begin{tabular}{|c|c|c|c|c|c|}
\hline No. & $\begin{array}{l}\text { Jumlah } \\
\text { Penerima }\end{array}$ & Tahun & Asnaf & Tipe/Pentasyarufan & Keterangan \\
\hline 1. & 18 Orang & 2019 & $\begin{array}{l}\text { Kurang } \\
\text { mampu }\end{array}$ & Konsumtif & - \\
\hline 2. & 20 Orang & 2019 & Fakir & Konsumtif & - \\
\hline 3. & 54 Orang & 2020 & $\begin{array}{l}\text { Kurang } \\
\text { mampu }\end{array}$ & Konsumtif & $\begin{array}{l}\text { Sebatang kara, Janda } \\
\text { dan Yatim piatu }\end{array}$ \\
\hline 4. & 24 Orang & 2020 & Fakir & Konsumtif & $\begin{array}{l}\text { Janda, Struk, Lansia, } \\
\text { Duda dan Cacat }\end{array}$ \\
\hline 5. & 22 Orang & 2020 & - & Konsumtif & Disabilitas \\
\hline
\end{tabular}

Sumber: diolah peneliti

Tabel di atas merupakan penerima bantuan dana ZIS untuk tahun 2019-2020, dimana pendistribusiannya ini dilakukan setiap bulannya pada tahun 2019 ada 10 paket sembako setiap bulan didistribusikan. Untuk tahun 2020 ada 25 paket sembako yang setiap bulan didistribusikan. Paket sembako yang didistribusikan ini bisa lebih dari rencana dan juga bisa kurang tergantung dari dana zakat yang diperoleh. Sedangkan untuk dibulan Ramadhan ada program khusus yang disebut Kado Ramadhan yang mana program ini ada beberapa tahapan yaitu tahap pertama sejumlah 50 paket sembako yang di distribusikan di Kecamatan yaitu Kecamatan Maliku, kemudian tahap kedua 50 paket sembako di Kecamatan Pandi Batu dan untuk tahap ketiga 50 paket di Kecamatan Kahayan Hilir. Ini belum termasuk pendistribusian pembagian takjil, karena pada bulan Ramadhan biasanya banyak muzakki atau donatur yang mebayar zakat ataupun ingin berinfak dan bersedekah. Disini peneliti melihat langsung kondisi penerima bantuan ZIS yang telah di data oleh LAZISMU Pulang Pisau, yang mana penerimanya orang-orang yang benar-benar membutuhkan. Penerima bantuan dana ZIS ini pekerjaannya hanya sebagai buruh bangunan, buruh tani, pemulung dan honorer. Ada beberapa jenis bantuan yang didistribusikan oleh pegurus LAZISMU Pulang Pisau diantaranya yaitu: ketahanan pangan dimana ketahanan pangan yaitu dalam bentuk sembako dan uang tunai, masker yang dibagikan saat terjadinya kabut asap dan pandemi Covid 19, pembagian 
takjil yang dilakukan setiap dibulan Ramadhan, kado Ramadhan, penyemprotan disinfektan dan pembersihan perumahaan dan fasilitas umum lainnya, pembagian sanitizer dan sabun cuci, pembagian APD kepada tim medis.

Berdasarkan penelitian yang telah dilakukan di Lembaga Amil Zakat Infak dan Sedekah Muhammadiyah (LAZISMU) Pulang Pisau dengan mewawancarai beberapa Informan atau Penerima bantuan zakat, infak dan sedekah (ZIS). Bahwa penerima bantuan mengalami perubahan sosial ekonomi, yaitu mereka sedikit terbantu walapun hanya dalam bentuk sembako tetapi itu sudah sedikit membantu perekonomian masyarakat kurang mampu dengan bantuan yang mereka terima dari LAZISMU Pulang Pisau, karena bantuan yang diberikan merupakan zakat konsumtif bukan produktif. Maka dari itu dananya hanya habis untuk digunakan sehari-hari. Zakat konsumtif merupakan zakat yang diberikan kepada delapan asnaf untuk memenuhi kebutuhan sehari-hari. Akan tetapi zakat konsumtif ini kurang begitu membantu untuk kebutuhan jangka panjang. Hal ini dikarenakan zakat konsumtif hanya memenuhi kebutuhan sehari-hari dan akan habis tanpa menghasilkan atau hanya untuk jangka pendek. Maka dari itu, diperlukan juga pola pendistribusian zakat produktif kepada para Mustahik (BAZNAS DIY, 2015). Zakat produktif adalah pemberian zakat yang dapat membuat para penerimanya menghasilkan sesuatu secara terus-menerus, dengan harta zakat yang telah diterimanya. Dengan demikian zakat produktif merupakan zakat di mana harta atau dana zakat yang diberikan kepada para mustahiq tidak dihabiskan, akan tetapi dikembangkan dan digunakan untuk membantu usaha mereka, sehingga dengan usaha tersebut mereka dapat memenuhi kebutuhan hidup secara terus-menerus (Widiastuti \& Rosyidi, 2015).

Dari pemamparan di atas dapat disimpulkan bahwa perubahan sosial ekonomi penerima bantuan dana zakat infak dan sedekah (ZIS), yaitu masyarakat kurang mampu sedikit terbantu dengan bantuan yang diberikan oleh LAZISMU Pulang Pisau yang dana berupa uang dan sembako. Bantuan ini hanya untuk meringankan kebutuhan pokok. Karena dana yang disalurkan oleh LAZISMU Pulang Pisau itu adalah dalam bentuk dana konsumtif bukan dana produktif, yang habis untuk digunakan sehari-hari. Karena penyaluran zakat secara kosumtif merupakan zakat yang diberikan kepada mustahik yang hanya sekali atau sesaat saja. Penyaluran zakat ini tidak disertai target terjadinya kemandirian ekonomi (pemberdayaan) dalam diri. Penerima bantuan dana ZIS ini hanya menerima bantuan berupa dana konsumtif. Masyarakat kurang mampu belum menerima bantuan berupa dana produktif, karena LAZISMU Pulang Pisau belum menjalankan program dana produktif LAZISMU Pulang Pisau hanya mengeluarkan bantuan berupa dana konsumtif. Untuk perubahan sosial ekonomi penerima bantuan dana ZIS masyarakat kurang mampu hanya mengalami perubahan yang tidak begitu banyak hanya perubahan kecil yaitu masyarakat penerima bantuan dana ZIS menerima bantuan hanya untuk memenuhi kebutuhan pangan sehari-hari. 


\section{KESIMPULAN}

Berdasarkan hasil penelitian dan analsis penelitian yang telah dilakukan mengenai Peranan Lembaga Amil Zakat Infak dan Sedekah Muhammadiyah (LAZISMU) dalam kesejahteraan masyarakat kurang mampu di Kecamatan Kahayan Hilir Kabupaten Pulang Pisau, Kalimantan Tengah dapat disimpulkan pertama, mekanisme pengumpulan dana zakat, infak dan sedekah (ZIS) di LAZISMU Pulang Pisau yaitu dengan tiga cara yaitu via transfer, datang langsung dan jemput langsung. Para muzakki atau donatur bisa memilih untuk membayarkan atau mengeluarkan zakat, infak dan sedekah di LAZISMU Pulang Pisau. Ada juga pengumpulan digital Fundraising melalui aplikasi seperti Ovo, Link Aja dll. Digital Fundraising yaitu salah satu upaya penghimpunan donasi melalui internet/web, yang berdonasi dapat berasal dari mana saja. Kedua, pendistribusian dana zakat, infak dan sedekah yang dilakukan oleh pengurus LAZISMU Pulang Pisau dan para relawan-relawan, yaitu didistribusikan dalam setiap bulan yang mana ada data base penerima bantuan dana ZIS dan saat adanya pandemi Covid 19 ada program yaitu penyemprotan disinfektan dan pembersihan perumahaan, pembagian masker, pembagian hand sanitizer, pembagian APD dan pendirian tenda-tenda ketahanan pangan. Terakhir, perubahan sosial ekonomi yang dialami masyarakat kurang mampu penerima bantuan dana zakat infak dan sedekah (ZIS), yaitu masyarakat kurang mampu sedikit terbantu dengan bantuan yang diberikan oleh LAZISMU Pulang Pisau yaitu berupa uang dan sembako. Bantuan ini hanya untuk meringankan kebutuhan pokok. Karena dana yang disalurkan oleh LAZISMU Pulang Pisau itu adalah dalam bentuk dana produktif yang habis untuk digunakan sehari-hari. para pengurus belum menjalankan program zakat produktif karena belum ada dana yang cukup untuk menjalankan program tersebut.

\section{DAFTAR PUSTAKA}

Abdul Mujieb \& Mabruri Tholhah Syafi'ah. (1994). Kamus Istilah Fiqh. PT. Pustaka Firdaus. Ali Mahmud Uqaily. (2017). Praktis dan Mudah Menghitung Zakat. Aqwam.

Almizan. (2016). Distribusi Pendapatan: Kesejahteraan Menurut Konsep Ekonomi Islam. Maqdis: Jurnal Kajian Ekonomi Islam, Vol. 1, No. 1.

Al-Qur'an dan Terjemah, DiterjemahkanYayasan Penyelenggara Penterjemah/Pentafsir Al Quraan, Jakarta: PT Intermasa 1971.

Afifuddin dan Ahmad Saebani Beni, Metodologi Penelitian Kualitatif, Bandung: Pustaka Setia, 2018.

Arikunto, S. Metodelogi Penelitian, Yogyakarta: Bina Aksara, 2006.

Amalia, Mahalli Kasyful, Potensi Dan Peranan Zakat Dalam Mengentaskan Kekurang mampuan Di Kota Medan, Jurnal Ekonomi dan Keuangan, Vol. 1, No.1, Desember 2012. JISFIM: Journal of Islamic Social Finance Management, Volume 2, No 1 Tahun 2021 http://jurnal.iain-padangsidimpuan.ac.id/index.php/JISFIM 
Andriyant, I. (2014). Pemberdayaan Zakat dalam Meningkatkan Kesejahteraan Umat. Ziswaf, Vol. 1, No. 2.

Atabik, A. (2015). Peranan Zakat dalam Pengentasan Kemiskinan. Jurnal Zakat Dan Wakaf.

Bachtiar S. Bachri, Meyakinkan Validitas Data Melalui Triangulasi Pada Penelitian

Kualitatif, Jurnal Teknologi Pendidikan, Vol.10, No. 1, April 2010.

Bagus Lorens, Kamus Filsafat, Jakarta: Gramedia, 1996.

Beik irfan Syauqi, “Analisis Peran Zakat dalam Mengurangi Kekurang mampuan : Studi

Kasus Dompet Dhuafa Republika”, Jurnal Pemikiran dan Gagasan - Vol II 2009.

Bungin M. Burhan, Penelitian Kualitatif (Komunikasi, Ekonomi, Kebijakan publik dan Ilmu

Sosial lainnya, Jakarta: Kencana, 2009.

BPS. (2019). Badan Pusat Statistik Kabupaten Pulang Pisau Kecamatan Kahayan Hilir Dalam Angka.

Departemen Pendidikan Nasional, D. P. N. (2005). Kamus Besar Bahasa Indonesia. Balai Pustaka.

Fanani. (2000). Zakat Kajian Berbagai Mazhab. PT. Remaja Rosda Karya.

Fazlur Rahman. (1996). Economic Doktrines of Islam. Dana Bhakti Wakaf.

Fenti Hikmawati, Metodologi Penelitian, Depok: Rajawali Pers, 2017.

Hafidhuddin, D. (2008). The Power Zakat Studi Perbandingan Pengelolaan Zakat Asia Tenggara, Malang. UIN Malang Press.

Huda Nurul, dkk, Zakat Perspektif Mikro-Makro (Pendekatan Riset), Jakarta: Prenadamedia Group, 2015.

KBBI. (n.d.). KBBI.

Kholiq, A. (2012). , Pendayagunaan Zakat, Infak dan Sedekah Untuk Pemberdayaan Ekonomi Masyarakat Miskin di Kota Semarang. Riptek, Vol. 6 No. I.

Makhlul Ilmi. (2002). Teori dan Praktek Lembaga Mikro Keuangan Syariah. UII Press.

Mukmin, H. (2014). Peranan Fakultas Dakwah sebagai Lembaga Dakwah Kampus (LDK) dalam Pemberdayaan Masyarakat Islam di Wilayah Lampung. Pusat Penelitian dan Penerbitan Lembaga Penelitian dan Pengabdian Kepada Masyarakat, IAIN Raden Intan Lampung.

Qaradhawi, Y. (2005). Spektrum Zakat dalam Membangun Ekonomi Kerakyatan. Daar ElSyoruk.

Qardhawi Yusuf, Fiqhu Az-Zakah, terj, Didin Hafidudin, et, al, “Hukum Zakat”, Bogor: Pustaka Liter Antar Nusa, 2004.

Sartika, M. (2008). Pengaruh Pendayagunaan Zakat Produktif terhadap Pemberdayaan Mustahiq pada LAZ Yayasan Solo Peduli Surakarta. Jurnal Ekonomi Islam, Vol. II, No 1. Sulaiman Rasjid. (1992). Fiqih Islam. Sinar Baru.

Sudaryono, Metodologi Penelitian, Depok: PT RajaGrafindonPersada, 2018.

JISFIM: Journal of Islamic Social Finance Management, Volume 2, No 1 Tahun 2021 http://jurnal.iain-padangsidimpuan.ac.id/index.php/JISFIM 
26 |Peranan Lembaga Amil Zakat Infak dan Sedekah Muhammadiyah dalam Kesejahteraan Masyarakat: Bukti dari Kalimantan Tengah

Sugiyono, Memahami Penelitian Kualitatif, Bandung: CV Alfabeta, 2010.

Teuku Muhammad Hasbi Ash Shiddiqy. (2006). Pedoman Zakat. PT. Pustaka Rizki Putra.

Widiastuti, T., \& Rosyidi, S. (2015). Model Pendayagunaan Zakat Produktif oleh Lembaga Zakat dalam Meningkatkan Pendapatan Mustahiq. JEBIS, Vol. 1, No. 1. 